\section{Nauplius}

The Journal OF The

Brazilian Crustacean Society

e-ISSN 2358-2936

www.scielo.br/nau www.crustacea.org.br

\title{
Association of Epialtus brasiliensis Dana, 1852 (Brachyura, Majoidea) with different species of seaweed
}

\author{
Priscila Granado' (D) orcid.org/0000-0002-5156-2789
}

Fernando Rafael De Grande ${ }^{2}$ (D) orcid.org/0000-0002-3047-1079

Tânia Marcia Costa ${ }^{2,3}$ (D) orcid.org/0000-0003-0230-8431
${ }^{1}$ Metropolitan University of Santos - UNIMES. 11045-002, Santos, São Paulo, Brazil. PG E-mail: prigranado@gmail.com
${ }^{2}$ Postgraduate Program in Biological sciences (Zoology), Botucatu Bioscience Institute, São Paulo State University - UNESP. 18618-000, Botucatu, São Paulo, Brazil. FRDG E-mail: frdegrande@gmail.com.
${ }^{3}$ Biosciences Institute - Coastal Campus of São Vicente, São Paulo State University - UNESP. 11330-900, São Vicente, São Paulo, Brazil.
TMC E-mail: tania.costa@unesp.br
ZOOBANK: http://zoobank.org/urn:lsid:zoobank.org:pub:C2C5C2FB-03AC-4211- AF8E-422B3459CA63

\section{Abstract}

Seaweed aggregates form secondary substrates on rocky shores, providing habitats for phytal organisms such as the spider crab Epialtus brasiliensis Dana, 1852. This species is one of the most abundant macroinvertebrate component from seaweed communities. Although the literature suggests that E. brasiliensis lives in many species of seaweed, their density has only been reported in communities of Sargassum spp. This study assessed the density of the spider crab E. brasiliensis associated with the seaweed Sargassum cymosum Agardh, 1820, Hypnea musciformis (Wulfen) Lamouroux and Acanthophora spicifera (Vahl) Borgesen. We expected to observe a higher density of E. brasiliensis in S. cymosum, which shows greater morphological complexity, followed by $H$. musciformis, with intermediate complexity, and then by $A$. spicifera, with low complexity. We found that the density of these crabs can be as abundant in $H$. musciformis as has been previously reported for S. cymosum, but in both species, the density was higher than in A. spicifera. Overall, our findings improve the knowledge of the phytal habitats used by E. brasiliensis in rocky shore environments.

CORRESPONDING AUTHOR P. Granado

prigranado@gmail.com

\section{KEYWORDS}

Majoidea, distribution, habitat complexity, rocky shore. 


\section{INTRODUCTION}

One of the main goals in ecology is to understand the distribution of organisms in the environment (Veiga et al.,2014; Jermacz et al., 2015). Habitat complexity is one of the regulatory factors in organismal differential distribution (Figueiredo et al., 2013; Gartner et al., 2013). In general, habitat complexity influences community dynamics, with higher complexity providing better protection against biotic and abiotic factors and greater availability of food resources (Cacabelos et al., 2010). In marine environments, habitat complexity may be due to physical structure and/or presence of biotic secondary substrates, such as mussels and seaweed (McCoy and Bell, 1991; Kovalenko et al., 2012; Carvalho and Barros, 2017). These organisms, when developed in an aggregate form, change the composition and availability of resources for other taxa, and have been defined as ecosystem engineers (Jones et al., 1994; 1997). Seaweed may also reduce the impacts of predation, desiccation and wave action for animals living in association with them (Borsje et al., 2011).

Among the ecosystem engineers, seaweeds show structural differences, such as distinct morphology, size, volume and number of branches, creating a range of complex environments (McCoy and Bell, 1991; Veiga et al., 2014). Mobile rocky shore species may seek refuge in seaweed beds, using seaweed as habitat (Williams and Seed, 1992; Clarkin et al., 2012). Crowe (1996), Blanco et al. (2011) and Clarkin et al. (2012) demonstrated that, due to their structural complexity, seaweeds show higher abundances of associated animals than bare rock surfaces.

The spider crab Epialtus brasiliensis Dana, 1852 is a phytal organism that inhabits the intertidal zone up to a depth of $10 \mathrm{~m}$. They are frequently found associated with seaweed on hard substrates (Negreiros-Fransozo and Fransozo, 1991; Mantelatto and Correa, 1996; Melo, 1996; Barros-Alves et al., 2018). This spider crab has a sharp dactyl curved inward on each pereiopod, which provides better grip onto the seaweed and prevents dislodgement by the force of water (Castaño and Campo, 2003). On the Atlantic coast, E. brasiliensis are distributed from northern Florida, USA to the Rio Grande do Sul, southern Brazil (Rathbun, 1925; Tamburus and Mantelatto, 2012). Reports have shown that these spider crabs are preyed upon by rocky shore fish, such as Stephanolepis hispidus Linnaeus, 1766 (Dubiaski-Silva and Masunari, 2008) and octopus Octopus insularis Leite and Haimovici, 2008 (Batista and Leite, 2016; Leite et al., 2016). Furthermore, E. brasiliensis may constitute the majority of the benthic epifauna in seaweed communities (Barros-Alves et al., 2018).

Epialtus bituberculatus Edwards 1874 was previously morphologically differentiated from E. brasiliensis due to the presence of a spine on the ventral surface of the propodus of their ambulatory pereiopods (a key diagnostic character). Even so, species differentiation is characterized as difficult and raises questions. Specifically, the distribution or misidentification of specimens may be due to similarities in morphological characteristics because they share the same habitat (see Tamburus and Mantelatto, 2016). Recently, however, their morphological and phylogenetic analyses unified both species as E. brasiliensis, and thus we used this classification here.

Despite the wide geographic distribution along the western Atlantic coast, their ecological potential as prey and their preponderance in seaweed communities, little is known about the life history, diet and habitat diversity of the spider crab E. brasiliensis. The species has been mostly reported to be associated with Sargassum spp. communities (see Negreiros-Fransozo and Fransozo, 1991; Mantelatto and Correa, 1996; Széchy and De Paula, 2000; Cobo and Barros, 2009; Barros-Alves et al., 2013; Barros-Alves et al., 2018). In habitats constituted by Sargassum cymosum Agardh, 1820, E. brasiliensis may reach densities of 1.27 to 34.67 individuals per liter (Barros-Alves et al., 2013). Epialtus brasiliensis has also been reported to occur in association with other seaweed genera, such as Acanthophora sp., Hypnea sp. and Padina sp. (see Negreiros-Fransozo and Fransozo, 1991; Melo, 1996; Masunari et al., 1998), but nothing is known about their density among other seaweed species. Considering that the density of E. brasiliensis is unknown in other habitats, the real importance of this spider crab in phytal communities is likely underestimated.

On the southeast Brazilian coast, Epialtus brasiliensis associates with the seaweed Sargassum cymosum, Hypnea musciformis (Wulfen) Lamouroux and Acanthophora spicifera (Vahl) Borgesen (Negreiros-Fransozo and Fransozo, 1991; Barros-Alves et al., 2013). The seaweed 
S. cymosum has a robust and bushy frond that can reach up to $60 \mathrm{~cm}$ in length, a thallus that can differ in cauloid, phylloid and appressory characters and phyllodes that are non-branched lanceolate, with a smooth edge that contain small teeth (Nassar, 2012). Hypnea musciformis shows a branched-cylindrical thallus with hook-shaped endings (tendrils) that can reach $20 \mathrm{~cm}$ in length (Nassar, 2012). Acanthophora spicifera shows a short and branched-cylindrical thallus that can reach $10 \mathrm{~cm}$ in length (Nassar, 2012). Based on the morphological characteristics of these three species, such as their size and branching, these seaweeds can be ordered in a gradient of complexity in which $S$. cymosum is more complex than $H$. muscifomis, followed by A. spicifera (Carvalho and Barros, 2017).

Herein, our goal was to test whether the density of E. brasiliensis varies according to the seaweed species with different levels of morphological complexity. Considering that pronounced habitat complexity can provide better protection and greater resource abundance, our expectation was to find a higher density of E. brasiliensis in the morphologically-most complex seaweed S. cymosum, followed by H. musciformis and lastly by $A$. spicifera.

\section{Material And Methods}

Since the abundance of crabs could be influenced by the frond size regardless of the seaweed species (Leite et al., 2007; Barros-Alves et al., 2018), we added seaweed volume as a co-factor in our analysis. The density of crabs (d) was calculated as the total number of E. brasiliensis individuals divided by the total seaweed volume (in L); it was expressed as individuals/L. Thus, we were able to test whether the density of E. brasiliensis varies among species of seaweed, regardless of the morphological complexity of the seaweed. Crabs and seaweed were collected in the mesolittoral fringe of a sheltered rocky shore from Enseada (2326'29"S 4504'34"W) and Lamberto (23⒉'55”S 4507’3”W) beaches, Ubatuba, São Paulo, southeastern Brazil. Samples were collected during low tide in April 2013. Previous studies demonstrated that crab density and seaweed volume may vary throughout the year (Masunari et al., 1998; Barros-Alves et al., $2013 ; 2018)$. Thus, we standardized the collection of crabs and target seaweed species in the same month to avoid the interference of seasonal factors in our model.

We followed Dethier et al. (1993) in using fifty-six $10 \times 10 \mathrm{~cm}$ squares to delimit sampling of the target seaweed species. Whole seaweed thalli were collected from the substrate with a spatula and packed inside plastic bags. Samples were frozen prior to laboratory analysis. In the laboratory, samples were thawed and individually examined under a stereomicroscope by screening all associated organisms. All samples were subsequently preserved in $10 \%$ formalin. Crabs were counted and identified to the species level according to Tamburus and Mantelatto (2016). After screening, seaweeds were identified according to Joly (1967) and their volume was measured by water displacement in a graduated cylinder, according to Montouchet (1979).

We used a zero-inflated generalized linear model (GLM) to evaluate whether the density of E. brasiliensis between seaweed species was influenced by seaweed volume. The dependent variable was the count data of $E$. brasiliensis density. Seaweed volume and species (three levels: S. cymosum, H. musciformis, and A. spicifera) were fitted as predictor factors. Data were fitted to a binomial distribution with a logit link function, and the overdispersion parameter was checked in the model. When relevant, post-hoc evaluations for all comparisons at the different levels between factors were performed. We provided results from the estimated best model (with the lowest AIC; Burnham and Anderson, 1998). The GLM analysis was performed in $R$ (R Core Team 2018), using the package MASS (Venables and Ripley, 2002) and lsmeans (Lenth, 2016) for post-hoc comparisons.

\section{ResULtS}

The density of the spider crab Epialtus brasiliensis as a function of volume differed between seaweed species (GLM test; Tab. 1). The highest density of E. brasiliensis (mean \pm standard error) was $37.39 \pm 8.27$ individuals $/ \mathrm{L}$ observed on Hypnea musciformis, which did not differ from $20.47 \pm 6.71$ individuals/L on Sargassum cymosum (Tukey test: $\mathrm{p}=0.98$; Fig. 1 ). However, the density of both species differed from that on Acanthophora spicifera, on which E. brasiliensis showed $8.02 \pm 3.07$ individuals per liter (Tukey test: $\mathrm{p}<0.005$; Fig. 1). In both $H$. musciformis and S. cymosum, the density 
of $E$. brasiliensis varied from 0 to 250 individuals/L, whereas the variation observed on $A$. spicifera was from 0 to 100 individuals/L. The volume of seaweed samples ranged from 3 to $50 \mathrm{~mL}$ (mean: $23.78 \mathrm{~mL}$ ) for H. musciformis, 10 to $100 \mathrm{~mL}$ (mean: $39.75 \mathrm{~mL}$ ) for S. cymosum and 10 to $50 \mathrm{~mL}$ (mean: $20.73 \mathrm{~mL}$ ) for A. spicifera. No relationship was observed between the volume of algae and the density of the crabs (Fig. 2).

Table 1. Epialtus brasiliensis density between the seaweed Sargassum cymosum, Hypnea musciformis and Acanthophora spicifera, according to GLM analysis. Density of E. brasiliensis was compared between treatments, according to the influence of seaweed species (categorical variable) and seaweed volume (continuous variable). Asterisks indicate a significant difference $(\mathrm{p}<0.001)$ according to the GLM analysis.

\begin{tabular}{lccc}
\hline Factor & Df. & $\mathrm{X}^{2}$ & $\mathrm{p}$ \\
\hline Density of Epialtus brasiliensis & & & $<0.0001^{*}$ \\
Seaweed species & 2 & 141.78 & $<0.0001^{*}$ \\
Volume & 1 & 290.42 & $<0.0001^{*}$ \\
Seaweed species ${ }^{*}$ Volume & 2 & 70.28 & \\
\hline
\end{tabular}

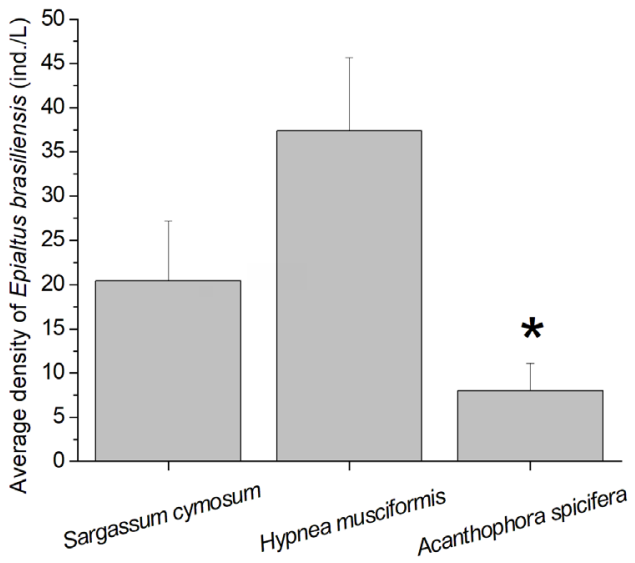

Figure 1. Mean density ( \pm standard error) of the spider crab Epialtus brasiliensis among the seaweed Sargassum cymosum, Hypnea musciformis and Acanthophora spicifera. Asterisks indicate a significant difference $(\mathrm{p}<0.005)$ according to the GLM analysis, in which the average density of the spider crabs was compared between the seaweed species, which were considered to influence the seaweed volume.

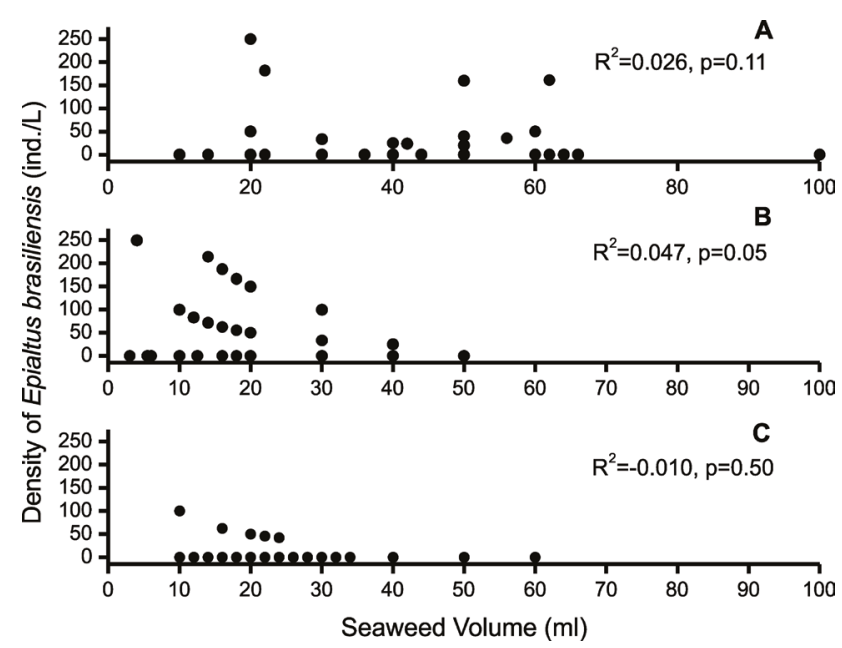

Figure 2. Linear regressions between density of the spider crab Epialtus brasiliensis and the seaweed volumes. A, Sargassum cymosum; B, Hypnea musciformis and C, Acanthophora spicifera.

\section{Discussion}

The spider crab Epialtus brasiliensis showed a higher occupation diversity in phytal habitats than has been previously reported (e.g., Negreiros-Fransozo and Fransozo, 1991; Mantelatto and Correa, 1996; Széchy and De Paula, 2000; Cobo and Barros, 2009; BarrosAlves et al., 2013; 2018). Herein, we showed that this species can live in the seaweed Sargassum cymosum, Hypnea musciformis, and Acanthophora spicifera. We showed that their density in $H$. musciformis habitats can be as high as that which, until now, has only been described for S. cymosum habitats. Although a higher density of these crabs was more frequently observed in H. musciformis and S. cymosum than in A. spicifera, we demonstrated that such variation is not directly associated with the structural complexity of the seaweed.

In the present work, we found the highest density of E. brasiliensis that has ever been reported, reaching a maximum of 250 individuals per liter (ind/L). In habitats composed of the seaweed $H$. musciformis and S. cymosum, the spider crab E. brasiliensis showed a mean density of 37.39 and 20.47 ind/L, respectively. These values are higher than those reported for $E$. brasiliensis by Barros-Alves et al. (2013) in S. cymosum on the beaches of Domingas Dias and Praia Grande at Ubatuba Bay - São Paulo State (minimum and maximum: 3.11 to 34.67 and 1.27 to 25.45 ind $/ \mathrm{L}$, respectively) and Barros-Alves et al. (2018) (mean: 12.10 and 5.97 ind/L, respectively). In Guaratuba Bay - Paraná State, Masunari et al. (1998) noted E. brasiliensis density ranging from 0.74 to 12.24 ind/L in a mixed assemblage of seaweed. 
The high densities of spider crabs in the present work can be explained by a taxonomic bias. Until recently, E. brasiliensis and E. bituberculatus were considered distinct species, but here, we considered them as a single species (sensu Tamburus and Mantelatto, 2016). In the present study, when we separately considered the density of the sensu morphotype called E. brasiliensis, we found mean densities of 19.97, 12.67 and 6.32 ind/L in habitats composed of $H$. musciformis, $S$. cymosum, and $A$. spicifera, respectively. Thus, even when considering the two morphotypes separately, the mean density of E. brasiliensis in this work was the highest ever described in habitats composed of H. musciformis and S. cymosum. Alternatively, the high density of E. brasiliensis observed in our study could be explained by hydrodynamics because our samples come from sheltered rocky shores. Indeed, Barros-Alves et al. (2018) reported that the density of this species is higher in more protected areas. Future studies may investigate this hypothesis by comparing sheltered and exposed rocky shore phytal habitats.

Sargassum cymosum are more complex than $H$. musciformis, followed by A. spicifera (Leite et al., 2007; Costa et al., 2012; Nassar, 2012), so it is expected that more complex environments, such as $S$. cymosum, would exhibit a higher abundance of spider crabs (Gartner et al., 2013). Usually, larger seaweed volumes are associated with greater complexity and consequently, a higher number of organisms (Hacker and Steneck, 1990; Curvelo and Corbisier, 2000; Gartner et al., 2013). This pattern was not, however, supported in the present study, since the density of E. brasiliensis was the same in S. cymosum and H. musciformis, the former of which had an intermediary volume among the analyzed seaweed species. Although less complex than S. cymosum, the seaweed H. musciformis has high nutritional value (Duffy and Hay, 1991; Stachowicz and Hay, 1999; Siddique et al., 2013), a feature that could explain the high density of E. brasiliensis in these seaweed species. Biological and ecological studies about these spider crabs are necessary to better understand why E. brasiliensis occurs at a higher density in $H$. musciformis and S. cymosum compared to A. spicifera. In this sense, future investigations of $E$. brasiliensis diet, their choice of different phytal habitats or their susceptibility to predators among different seaweed beds could help clarify this issue.
We observed no relationship between the volume of algae and the density of the crabs. Barros-Alves et al. (2018) also found that E. brasiliensis density was not directly associated with seaweed volume. During seasonal periods, when seaweed shows a dense and complex architecture, some generalist and opportunistic species of Panopeidae and Pilumnidae crabs may use these phytal habitats as foraging areas, thus modifying the structure of E. brasiliensis assemblages (Barros-Alves et al., 2018). Our data also corroborated the hypothesis in which the density of E. brasiliensis may be favored when seaweed beds show low structural complexity; in our study, high densities of E. brasiliensis were observed in samples composed of small-sized seaweed, whose volumes varied from 3 to $100 \mathrm{~mL}$. Therefore, as in Barros-Alves et al. (2018), we found that the density of E. brasiliensis was not directly associated with seaweed volume. The low structural complexity (small size) of seaweed can support a high density of these crabs.

In conclusion, we improved the knowledge of the phytal habitats used by the spider crab E. brasiliensis. The density of these crabs can also be abundant in other seaweed species (H. musciformis), as previous works had only reported for $S$. cymosum, but the density is not associated with the structural complexity of seaweed species. Our findings will help future studies to consider a greater diversity of phytal habitats of $E$. brasiliensis and, therefore, clarify the role of these crabs in seaweed communities.

\section{ACKNOWLEDgementS}

The authors would like to thank the Laboratory of Ecology and Animal Behavior (UNESP - São Vicente) team for their assistance during the field and laboratory activities, Murilo Marochi and Bruno Fogo for their help with the statistical analysis, Ronaldo Christofoletti for his support and co-supervision in this work and Gray Williams for his comments. The Coordination for the Improvement of Higher Level Personnel (CAPES) granted a scholarship to the Biosciences Institute Graduate Program, São Paulo State University (UNESP) - Botucatu. TMC was supported by the São Paulo Research Foundation (FAPESP), process No. 2010/09763-9. 


\section{References}

Barros-Alves, S.P.; Alves, D.F.R. and Cobo, V.J. 2013. Comparison of the population biology of Epialtus bituberculatus from two rocky shores with distinct hydrodynamic patterns. Journal of the Marine Biological Association of the United Kingdom, 93: $1-10$.

Barros-Alves, S.P.; Alves, D.F.R. and Cobo, V.J. 2018. Brachyuran crab (Crustacea, Decapoda) assemblage associated with Sargassum cymosum in southeastern Brazil. Marine Biodiversity, 48: 2043-2055.

Batista, A.T. and Leite, T.S. 2016. Octopus insularis (Cephalopoda: Octopodidae) on the tropical coast of Brazil: where it lives and what it eats. Brazilian Journal of Oceanography, 64: 353-364.

Blanco, C.G.; Gusmão-Junior, J.B.L.; Christofoletti, R.A. and Costa, T.M. 2011. Hydrodynamism and its influence on the density of the decorator crab Microphrys bicornutus (Mithracidae) on intertidal rocky shores from a subtropical region. Marine Biology, 7: 727-731.

Borsje, B.W.; Wesenbeeck, B.K.V.; Dekker, F.; Paalvast, P.; Bouma, T.J.; Katwijkf, M.M.V. and de Vries, M.B. 2011. How ecological engineering can serve in coastal protection. Ecological Engineering, 37: 113-122.

Burnham, K.P. and Anderson, D.R. 1998. Practical use of the information-theoretic approach. p. 75-117.In: K.P. Burnham and D.R. Anderson (eds), Model Selection and Inference. New York, Springer.

Cacabelos, E.; Olabarria, C.; Incera, M. and Troncoso, J.S. 2010. Effects of habitat structure and tidal height on epifaunal assemblages associated with macroalgae. Estuarine and Coastal Marine Science, 89: 43-52.

Carvalho, L.R.S. and Barros, F. 2017. Physical habitat structure in marine ecosystems: the meaning of complexity and heterogeneity. Hidrobiologia, 797: 1-9.

Castaño, N.C. and Campo, N.H. 2003. Los cangrejos araña (Decapoda: Brachyura: Majoidea) del Caribe Colombiano. Biota Colombiana, 4: 261-269.

Clarkin, E.; Maggs, C.A.; Arnott, G.; Briggs, S. and Houghton, J.D.R. 2012. The colonization of macroalgal rafts by the genus Idotea (sub-phylum Crustacea; order Isopoda): an active or passive process? Journal of the Marine Biological Association of the United Kingdom, 92: 1273-1282.

Cobo, V.J. and Barros, S.P. 2009. Reproductive output of the spider crab Epialtus bituberculatus (H. Milne Edwards, 1834) (Crustacea, Decapoda, Brachyura) associated with beds of the alga Sargassum cymosum (C. Agardh, 1820) on the southeastern Brazilian coast. Invertebrate Reproduction \& Development, 53: 53-58.

Costa, I.O; Caires, T.A.; Pereira Filho, G.H. and Nunes, J.M.C. 2012. Macroalgas bentônicas associadas a bancos de Hypnea musciformis (Wulfen) J.V. Lamour. (Rhodophyta Gigartinales) em duas praias do litoral baiano. Acta Botanica Brasilica, 26: 493-507.

Crowe, T.P. 1996. Different effects of microhabitat fragmentation on patterns of dispersal of an intertidal gastropod in two habitats. Journal of Experimental Marine Biology and Ecology, 206: 83-107.

Curvelo, R.R. and Corbisier, T.N. 2000. The meiofauna associated with Sargassum cymosum at Lázaro Beach, Ubatuba, São Paulo. Revista Brasileira de Oceanografia, 48: 119-130.
Dethier, M.N.; Graham, E.S.; Cohen, S. and Tear, L.M. 1993. Visual versus random-point percent cover estimations: 'objective' is not always better. Marine Ecology Progress Series, 96: 93-100.

Dubiaski-Silva, J. and Masunari, S. 2008. Natural diet of fish and crabs associated with the phytal community of Sargassum cymosum C. Agardh, 1820 (Phaeophyta, Fucales) at Ponta das Garoupas, Bombinhas, Santa Catarina State, Brazil. Journal of Natural History, 42: 1907-1922.

Duffy, J.E. and Hay, M.E. 1991. Food and shelter as determinants of food choice by an herbivorous marine amphipod. Ecology, 72: 1286-1298.

Figueiredo, B.R.S.; Mormul, R.P. and Benedito, E. 2013. Nonadditive effects of macrophyte cover and turbidity on predator-prey interactions involving an invertivorous fish and different prey types. Hydrobiologia, 716: 21-28.

Gartner, A.; Tuya, F.; Lavery, P.S. and McMahon, K. 2013. Habitat preferences of macroinvertebrate fauna among seagrasses with varying structural forms. Journal of Experimental Marine Biology and Ecology, 439: 143-151.

Hacker, S.D. and Steneck, R.S. 1990. Habitat architecture and the abundance and body-size-dependent habitat selection of a phytal amphipod. Ecology, 71: 2269-2285.

Jermacz, L.; Dzierzynska, A.; Poznanska, M. and Kobak, J. 2015. Experimental evaluation of preferences of an invasive PontoCaspian gammarid Pontogammarus robustoides (Amphipoda, Gammaroidea) for mineral and plant substrata. Hydrobiologia, 746: 209-221.

Joly, A.B. 1967. Gêneros de algas marinhas da costa atlântica latino-americana. São Paulo, Ed. USP, 462p.

Jones, C.G.; Lawton, J.H. and Shachak, M.1994. Organisms as ecosystem engineers. Oikos, 69: 373-386.

Jones, C.G.; Lawton, J.H. and Shachak, M. 1997. Positive and negative effects of organisms as physical ecosystem engineers. Ecology, 78: 1946-1957.

Kovalenko, K.E.; Thomaz, S.M. and Warfe, D.M. 2012. Habitat complexity: approaches and future directions. Hydrobiologia, 685: 1-17.

Leite, F.P.P.; Tanaka, M.O. and Gebara, R.S. 2007. Structural variation in the brown alga Sargassum cymosum and its effects on associated amphipod assemblages. Brazilian Journal of Biology, 67: 215-221.

Leite, T.S.; Batista, A.T.; Lima, F.D.; Barbosa, J.C. and Mather, J. 2016. Geographic variability of Octopus insularis diet: from oceanic island to continental populations. Aquatic Biology, 25: $17-27$.

Lenth, R.V. 2016. Least-Squares Means: The R Package lsmeans. Journal of Statistical Software, 69: 1-33.

Mantelatto, F.L.M. and Correa, E.K. 1996. Composition and seasonal variations of the Brachyurian crabs (Crustacea, Decapoda) living on Sargassum cymosum in the Ubatuba region, São Paulo, Brazil. Bioikos, 9-10: 22-31.

Masunari, S.; Oliveira, E. and Kowalczuk, V.G.L. 1998. Crustacea Decapoda da praia rochosa da Ilha do Farol, Matinhos, Paraná. I. Distribuição temporal de densidade das populações. Revista brasileira de Zoologia, 15: 219-239.

McCoy, E.D. and Bell, S.S.1991. Habitat structure: the evolution and diversification of a complex topic. p. 3-27. In: S.S. Bell; E.D. McCoy and H.R. Mushinsky (eds), Habitat structure the 
physical arrangement of objects in space. London, Chapman and Hall.

Melo, G.A.S. de 1996. Manual de identificação dos Brachyura (caranguejos e siris) do litoral brasileiro. São Paulo, Ed. Plêiade/FAPESP, 604p.

Montouchet, P.C.G. 1979. Sur la communauté des animaux vagiles associes à Sargassum cymosum C. Agardh, à Ubatuba, Etat de São Paulo, Brésil. Studies on Neotropical Fauna and Environment, 14: 33-64.

Nassar, C. 2012. Macroalgas marinhas do Brasil: guia de campo das principais espécies. Rio de Janeiro, Ed. Technical Books, 178p.

Negreiros-Fransozo, M.L. and Fransozo, A. 1991. Larval stages of Epialtus brasiliensis Dana, 1852 (Decapoda, Brachyura, Majidae) reared in the laboratory, with notes on characters of the majid subfamilies. Crustaceana, 60: 200-212.

Rathbun M.J. 1925. The spider crabs of America. Bulletin of the United States National Museum, 129: 1-613.

Siddique, M.A.M.; Aktar, M. and bin Mohd Khatib, M.A. 2013. Proximate chemical composition and amino acid profile of two red seaweeds (Hypnea pannosa and Hypnea musciformis) collected from St. Martin's Island, Bangladesh. Journal of fisheries sciences.com, 7: 178-186.

Stachowicz, J.J. and Hay, M.E. 1999. Reducing predation through chemically mediated camouflage: indirect effects of plant defenses on herbivores. Ecology, 80: 495-509.
Széchy, M.T.M. and De Paula, E. 2000. Padrões estruturais quantitativos de bancos de Sargassum (Phaeophyta, Fucales) do litoral dos estados do Rio de Janeiro e São Paulo, Brasil. Revista Brasileira de Botanica, 23: 121-132.

Tamburus, A.F. and Mantelatto, F.L. 2012. Range extensions along western Atlantic for Epialtidae crabs (Brachyura, Majoidea) genera Acanthonyx Latreille, 1828 and Epialtus H. Milne Edwards, 1834. Nauplius, 20: 179-186.

Tamburus, A.F. and Mantelatto, F.L. 2016. A multifaceted comparison between the spider crabs Epialtus bituberculatus and Epialtus brasiliensis (Brachyura: Majoidea: Epialtidae) in the neotropical areas of the western Atlantic: morphology, morphometry and DNA markers. Neotropical Biodiversity, 2: $124-140$.

Veiga, P.; Rubal, M. and Sousa-Pinto, I. 2014. Structural complexity of macroalgae influences epifaunal assemblages associated with native and invasive species. Marine Environmental Research, 101: 115-123.

Venables, W.N. and Ripley, B.D. 2002. Statistics and Computing. Modern Applied Statistics with S, Fourth ed. New York, Springer-Verlag, 495p.

Williams, G.A. and Seed, R. 1992. Interactions between macrofaunal epiphytes and their host algae. p. 189-211. In: D.M. John; S.J. Hawkins and J.H. Price (eds), Plant-Animal Interactions in the Marine Benthos. Oxford, Clarendon Press. 